\title{
Kissing Frogs: The Challenges Of Becoming A Successful Entrepreneur
}

\author{
George Dierberger, Augsburg University, USA \\ Marc Isaacson, Augsburg University, USA \\ Cory Erickson, Augsburg University, USA \\ Thomas P. Dierberger, Business Executive, USA
}

\begin{abstract}
"Kissing Frogs: The challenges of becoming a successful entrepreneur" explores the difficulties of creating, sustaining and succeeding as a business owner. This research is supplemented with data from a national survey to entrepreneurs (355) through Qualtrics ${ }^{\mathrm{TM}}$, a global research organization. The respondents represented 42 states from a diverse group of self-identified entrepreneurs from a variety of industries.
\end{abstract}

To summarize, the paper will analyze the following topics in detail:

1) The importance of the mission and vision for the organization

2) The motivation for starting the business

3) The inspiration for the business idea

4) The importance of perseverance

Keywords: Entrepreneur; Innovation; Risk Management; Ideation; Leadership; Organization Behavior; Iteration; Collaboration; Perseverance

Suggested Courses: The case will be most appealing to undergraduate business seniors and MBA students interested in management, finance, accounting and marketing.

\section{INTRODUCTION}

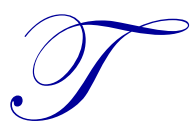

he term "Kissing Frogs" originally came from the Brothers' Grimm and their fairy tale, The Frog Prince in 1889 (Denecke, 2019). A princess happens upon a frog in a pond and the frog persuades the princess all she has to do is give him a kiss and he will turn into a handsome prince. Similar to the princess in the fairy tale, entrepreneurs seek businesses that offer a promise of success - a chance to find their respective "prince."

In parallel with the Grimm's fairy tale, Art Fry, the 3M scientist who invented Post-it ${ }^{\circledR}$ brand notes (Fry, 2017), was discussing the frustrating and chaotic challenges of launching a radical new business, and he stated, "You to have to kiss a lot of frogs to find a prince." The metaphor resonated with the authors as they began researching entrepreneurs and their business ventures.

The Post-it ${ }^{\circledR}$ Note business was a success due to Mr. Fry's perseverance. Fry's product idea was challenged when several market tests were unsuccessful due to the high price of the Post-it ${ }^{\mathbb{B}}$ Notes compared to regular paper and a simple staple. Finally, after two failed market tests, the product found success when the marketing team instigated a sampling program by handing out 10 -sheet samples of Post-it ${ }^{\mathbb{B}}$ Notes to potential customers, along with an incentive to purchase the product using a $10 \%$ off coupon. The game-changer was getting a sample into the hands of consumers so they could use the product and experience the increased productivity and communication generated by the attentiongetting, bright yellow notes. Post-it Notes became one of the most successful products in the 1980s and 1990s and Mr. Fry became a spokesperson for innovation. The key lesson for entrepreneurs is this: Customers need to sample the product to help generate awareness, trial and ongoing usage. 
Post- It ${ }^{\circledR}$ Notes were not an overnight success story, with the adhesive originally conceived in 1968. Fry attended a quarterly technical forum in 1974 and the keynote speaker was another 3M scientist, Spencer Silver, who discussed a unique adhesive he had developed. Silver's innovation had an unusual molecular structure, yielding an adhesive strong enough to cling to objects but weak enough to allow for a temporary bond; in essence, a repositionable adhesive. At the time, Silver had an interesting adhesive with unique properties, but he needed help and collaboration to find a product that could be commercialized. Fry remembered the repositionable adhesive when he was singing in his church choir and was frustrated with using slips of paper to mark the pages of his psalm book; it occurred to him that Silver's adhesive could be put to use to create a better bookmark. If it could be coated on paper, Silver's adhesive would hold a bookmark in place without damaging the page on which it was placed. The next day, Fry requested a sample of the adhesive. He began experimenting, coating only one edge of the paper so that the portion extending from a book would not be sticky. Fry used some of his experiments to write notes to his manager which led him to the conclusion that what he really had was a communication device, not a bookmarker. Mr. Fry started to give samples to the administrative assistants of executives at $3 \mathrm{M}$ and kept track of when they asked for another sample. He wanted to get an idea of the consumption rates of the product to understand demand and a possible forecast (Fry, 2017).

It took Mr. Fry six years, but Post-it ${ }^{\circledR}$ Notes were finally released to the national market in 1980 and in 1981, 3M named Post-it ${ }^{\mathbb{R}}$ Notes its Outstanding New Product. In 1980 and 1981, the Post-it ${ }^{\mathbb{R}}$ Note team received 3M's Golden Step Award, given to teams who create major new products that are significantly profitable and over $\$ 10$ million in annual sales. Today, Post-it ${ }^{\mathbb{R}}$ Notes are a significant global business for $3 \mathrm{M}$. Mr. Fry displayed perseverance despite unsuccessful test markets, but he kept experimenting, iterating, collaborating, learning and accumulating knowledge. With that knowledge from past failures, he (and the product) became better each time he did not succeed. The other quote he shared with the author was the difficulty in manufacturing Post it ${ }^{\mathbb{B}}$ Notes (there are four main components to adhesive notes). Mr. Fry stated, "Good, I want it to be difficult, so other companies will have trouble copying it" (Fry, 2017).

According to Dess (2019), in his book, Strategic Management there are many great product ideas in large corporations and small entrepreneurial companies that fail for a variety of reasons: timing could be wrong, the competition may have a dominant market position, or the organization may not invest in marketing and supporting the product. Dess (2019) states that the more radical the idea, the more expensive it can be to commercialize and the greater the chance of failure. Incremental change, making something faster, smaller, changing the color, is less risky and very appealing to large companies and entrepreneurs who are afraid of taking a significant risk (Dess, 2019).

The challenges that entrepreneurs face can be both internal (things they control) or external (things they influence but do not control):

- Internal roadblocks due to a lack of resources, marketing support, or being deemed a low priority because of politics or financial commitments to other programs.

- External roadblocks due to government regulations, competition or a poor economy.

What motivates entrepreneurs? How do they pick themselves up and keep going? Where do they receive the inspiration for their ideas and innovations? How often have they failed? How important is the mission and vision to the success of their organization? The survey the authors created, tested and implemented will shed light on the drive behind entrepreneurs and where they receive the inspiration for their businesses.

\section{Entrepreneurship Defined}

Entrepreneurship has many definitions, ranging from "turning an idea into a business" to individuals who pursue opportunities for the purpose of exploiting future goods and services (Barringer \& Ireland, 2019).

The word entrepreneur is derived from the French words, "entre" (between) and "prendre" (to take). According to Barringer, the word was originally used to describe people who "take on the risk" between buyers and sellers (Barringer \& Ireland, 2019). Merriam-Webster defines an entrepreneur as someone who organizes, manages, and assumes the risks of an enterprise (Editor, 2018). The term has evolved to include both for-profit and non-profit 
entrepreneurs. The authors will illustrate the key concepts with several examples of entrepreneurs we have worked with over the past five years.

What does it take to be a successful entrepreneur? In Table 1, Gregory Dess (2019), in his book, Strategic Management, states that entrepreneurs have the following characteristics:

Table 1. Entrepreneur Characteristics

\begin{tabular}{l|l}
\hline \multicolumn{1}{c}{ Characteristic } & \multicolumn{1}{c}{ Definition } \\
\hline Higher Self Efficacy & Higher levels of self-confidence and a stronger belief in their own destiny \\
\hline Higher Conscientiousness & Higher degree of organization, persistence, hard work, and a drive to reach goals \\
\hline Higher openness to experience & Intellectual curiosity and a desire to explore unique ideas \\
\hline Higher emotional stability & $\begin{array}{l}\text { Ability to handle ambiguity and maintain even emotions during stressful periods, and } \\
\text { less likely to be overcome by anxieties }\end{array}$ \\
\hline Lower agreeableness & A bit of Machiavelli: they look out for their own self interest \\
\hline
\end{tabular}

Dess (2019) believes that successful entrepreneurs have the following personality traits:

- Vision that can transform the organization

- Self-efficacy that drives belief in their ability

- Dedication and drive that require hard work and unique perseverance

- Commitment to excellence on all levels of the organization

The traits identified by Dess (2019) helps entrepreneurs handle challenges in starting a business and persevering with the day-to-day managing of the business.

In Table 2, Barringer believes that passion is important for an entrepreneur to be successful. Many entrepreneurs create businesses to help people, to gain financial freedom or simply to be their own boss. The passion people have for their businesses can make the difference between success and failure. The five primary reasons why passion is important for the launch of a successful organization (Barringer \& Ireland, 2019) include:

Table 2. Entrepreneur Passion

\begin{tabular}{l|l}
\hline \multicolumn{1}{c}{ Reason Why Passion is Important } & \multicolumn{1}{c}{ Explanation } \\
The ability to learn and iterate & It takes passion and creativity to keep improving or perfecting the product \\
\hline $\begin{array}{l}\text { A willingness to work hard } \\
\text { Ability to listen to feedback on your }\end{array}$ & $\begin{array}{l}\text { Entrepreneurs work long hours } \\
\text { limitations }\end{array}$ \\
\hline that discern between people who are providing constructive criticism versus ones \\
Ability to overcome setbacks & $\begin{array}{l}\text { Every entrepreneur (Collins, 2001) has setbacks. The energy to continue comes from } \\
\text { passion for an idea. }\end{array}$ \\
\hline Perseverance and persistence & Passion is what drives an entrepreneur to get through the tough times. \\
\hline
\end{tabular}

Barringer believes that passion drives success and that helps businesses succeed by promoting hard work, collaboration, iteration and perseverance when things go poorly.

On a global basis, entrepreneurship generates a tremendous amount of interest. The Global Entrepreneurship Monitor (GEM) is one of the world's foremost authorities on entrepreneurship. GEM is affiliated with universities all over the world and is frequently used as a reference by the World Bank and other international organizations (GEM, 2019). GEM has collected data for over 20 years, from 112 countries and over 300 academic institutions. One of the things that GEM tracks is the total early stage entrepreneurial activity (TEA). According to GEM the highest rates of entrepreneurship are in low-income countries where good jobs are not as plentiful (Barringer \& Ireland, 2019). Table 3 is a summary of major countries and the percentages of people in the early stage entrepreneurial activity for people with businesses less than 3.5 years old. The data is based on work from GEM (GEM, 2019). 
Table 3. Global Entrepreneur Monitor Country Results

\begin{tabular}{|c|c|}
\hline Country & Percent of Population Starting a New Business \\
\hline Brazil & $21 \%$ \\
\hline Chile & $25.9 \%$ \\
\hline China & $12.8 \%$ \\
\hline Germany & $4.7 \%$ \\
\hline Philippines & $17.2 \%$ \\
\hline Spain & $5.7 \%$ \\
\hline United Kingdom & $6.9 \%$ \\
\hline United States & $11.9 \%$ \\
\hline
\end{tabular}

In the United States, one out of every eight people are involved in some type of entrepreneur activity. According to Global Entrepreneurship Monitor (GEM), there is a correlation between the number of businesses started and the age of the entrepreneur. The majority of the businesses were started by people between the age of 18 to 44 (Bosma, 2018). In the survey data, a significant portion of the entrepreneurs had started multiple businesses, and many felt they improved through each experience.

\section{ENTREPRENEUR SURVEY}

The authors have worked with over 75 entrepreneurs in the past 12 years, helping them with strategy, business operations and marketing plans. The authors have heavily balanced our perspective by working with commercial businesses and non-profit organizations. Over the course of the past 15 years, several patterns started to emerge in terms of how and where entrepreneurs derived the ideas with which they started their businesses and what motivated them to do so. With a curious spirit and tangible desire to learn more about entrepreneurs, we created a survey in July of 2018. The survey was tested with 77 entrepreneurs from the state of Minnesota in September and October and adjusted to add specificity and clarity to some of the questions. In March of 2019, the authors contracted with Qualtrics, a global research firm, with offices in over 90 countries that work with over 2,000 universities. Once the qualification parameters were established, Qualtrics recruited over 355 entrepreneurs from 42 different states in the United States. The entrepreneurs were asked a series of questions regarding their own personal experiences. The questions included the following:

- How many businesses have you started? How many failed?

- What inspired your business idea?

- Is your business a product or a service?

- What type of industry do you participate in?

- Have you commercialized your product or service?

- The length of time it took to launch the product?

- Have you written a formal business plan?

- Do you have a mission and vision statement?

- What was your motivation to start your own business?

The survey was adjusted after the 77-person beta test to add clarity to some of the questions. Due to time constraints and the cost of the study, the survey only focused on entrepreneurs who started for-profit organizations. The survey was then sent out nationwide to entrepreneurs through Qualtrics to the first 355 qualified respondents. Per the researchers' request, the respondents had to represent:

- The majority of the United States

- A balanced number of men and women

- A variety of businesses

- A mixture of educational backgrounds

- Multiple businesses in different industries 
The following are the demographic data points from the survey:

- 42 states were represented

- There were 201 females and 154 males

- The majority of respondents $(69.5 \% / 247)$ self-identified as Caucasian

- The ages ranged from 18-50+ years. The majority of entrepreneurs were over the age of 30 . The data are consistent with previously noted journal articles, with entrepreneurs having more experience and access to funding.

- There is a correlation between those entrepreneurs over the age of 50 and how many business ventures have been attempted

- Approximately $63 \%$ of the entrepreneurs surveyed earn less than $\$ 100,000$ a year

- In terms of education, $63.9 \%$ of the people surveyed have an undergraduate or graduate degree or a doctorate

Table 4 is an excellent summary of the demographics of the survey. The age of the survey is a bell-shaped curve. The data strongly suggests that entrepreneurs with at least a 4-year degree were the majority of the entrepreneurs interviewed.

Table 4. Survey Demographics

\begin{tabular}{|c|c|}
\hline \multicolumn{2}{|c|}{ Gender } \\
\hline Female $55.4 \%$ & \\
\hline \multicolumn{2}{|l|}{ Male $44.6 \%$} \\
\hline Race & Number of Respondents \\
\hline Caucasian & 247 \\
\hline Asian American & 8 \\
\hline Native American & 6 \\
\hline African American & 42 \\
\hline Hispanic American & 29 \\
\hline Other or prefer not to identify & 10 \\
\hline \multicolumn{2}{|l|}{ Age } \\
\hline $18-24$ & 34 \\
\hline $25-29$ & 46 \\
\hline $30-34$ & 65 \\
\hline $35-39$ & 60 \\
\hline $40-49$ & 65 \\
\hline 50 plus & 76 \\
\hline \multicolumn{2}{|c|}{ Education level } \\
\hline High School Degree & 68 \\
\hline Associates Degree & 50 \\
\hline Bachelor's Degree & 113 \\
\hline Master's Degree & 101 \\
\hline Doctorate & 13 \\
\hline \multicolumn{2}{|c|}{ Income levels } \\
\hline$\$ 50 \mathrm{k}$ or less & 100 \\
\hline$\$ 50-\$ 100 \mathrm{k}$ & 124 \\
\hline$\$ 100 \mathrm{k}-\$ 150 \mathrm{k}$ & 77 \\
\hline$\$ 150-\$ 250 \mathrm{k}$ & 36 \\
\hline$\$ 250 \mathrm{k}$ plus & 27 \\
\hline
\end{tabular}

A significant number of entrepreneurs surveyed had started more than one business. Table 5's data reinforces the notion that entrepreneurs like to start businesses and they tend to improve each time they start a new business. The authors, who have started 11 businesses over the past 20 years, also can attest to this phenomenon - we improved through iteration and experience and by rarely making the same mistake twice. One lesson learned was the need to keep start-up costs as low as possible and effectively manage cash flow by maintaining lower inventory, especially 
for a seasonal business. A critical mistake that many entrepreneurs make is tying up capital in inventory that can be used for other purposes. The authors believe that each business started takes time and energy but there is an opportunity cost if you choose poorly. In our survey, over 200 of the entrepreneurs (roughly 59\%) started more than one business.

Table 5. Survey Results for Businesses Started

\begin{tabular}{|c|c|}
\hline Number of entrepreneurs & Number of businesses started \\
\hline 62 & 0 \\
\hline 172 & 1 \\
\hline 167 & 2 \\
\hline 27 & 3 \\
\hline 14 & 4 plus \\
\hline
\end{tabular}

An example of a serial entrepreneur is Stian Knutsen from Oslo, Norway. Mr. Knutsen has started six businesses over the past 20 years and a key lesson learned from Mr. Knutsen was not to rely too much on one customer; also, to never give up. Mr. Knutsen owned a pizza factory in Oslo that supplied frozen pizza to grocery stores, mass market and convenience stores. He had over $50 \%$ of his business with one retail customer. The leverage the customer had over Mr. Knutsen was crippling in terms of the demands for price reductions and payment terms. It literally put the business on the brink of insolvency and Mr. Knutsen was forced to close the business (Knutsen, 2019). Mr. Knutsen found that passion and perseverance have been critical to his success. He has kissed many frogs on his way to commercializing a new packaging concept called Q-Bic, Smart Packaging. His past failures sharpened his resolve and helped him avoid the mistakes he had made with his past business failures.

In Table 6, based on the entrepreneurs' responses, we have documented the number of businesses that are still functioning $(72 \%)$ versus entities that are no longer viable (28\%).

Table 6. Survey Results for Functioning Businesses

\begin{tabular}{l|c}
\hline \multicolumn{1}{c}{ Number of businesses functioning } & Number of respondents \\
\hline No longer in business & 101 \\
\hline One functioning business & 171 \\
\hline Two functioning businesses & 49 \\
\hline Three functioning businesses & 11 \\
\hline Four or more functioning businesses & 14 \\
\hline
\end{tabular}

Table 6 addresses the difficulty of sustaining an on-going business with close to a $30 \%$ failure rate. There are many external economic factors you do not control when it comes to managing your own business. A recession or a pandemic like the coronavirus forced many small businesses to the brink of bankruptcy or forced many of them to close. These external threats, are something owners who run on very tight margins, cannot plan for and usually are the death of the business entity.

\section{VISION STATEMENTS}

Businesses create vision statements to communicate a desired future for the organization. A vision statement is a longterm goal describing the "what" an organization wants to become. It is a clear sense of the future and the actions needed to get there (Kinicki, 2019). A vision is a goal that is profoundly inspiring, overarching, and long-term (Dess, 2019). In a survey of executives from 20 different countries, respondents were asked to identify the key traits of a leader. Ninety-eight percent responded that a "strong sense of mission" was the most important (Dess, 2019). What is the dream of the organization? What will stretch the organization and motivate people to rethink what is possible to achieve? (Belgard \& Fisher, 1988). A vision statement should be consistent with the mission, strategy and philosophy of the organization. Some examples include:

- Mayo Clinic's vision statement is "to provide an unparalleled experience as the most trusted partner for health care" (Mayo Clinic, 2019). Dr. Rahul Kashyap, a Mayo Clinic Physician stated that the value 
proposition for all employees is that the "needs of the patient come first" (Kashyap, 2018).

- Disneyland's vision is "To be the happiest place on earth"

- Medtronic's vision statement is "Restoring patients to full life"

- The vision of McDonald's is "To be the world's best quick service restaurant"

- Google's vision statement is "To organize the world's information and make it universally accessible and useful."

- Facebook's vision statement is "To give everyone in the world the power to share and make the world more open and connected."

Vision statements do not guarantee success for an organization. At times, a company's vision statement can backfire. Belgard \& Fisher (1988) state that visions fail for many reasons including the following:

- The walk does not match the talk. Senior management does not adhere to the vision (Volkswagen).

- Irrelevance. The vision is not anchored in reality.

- Not the holy grail. Leadership constantly tries out new management fads (Six Sigma, Scrum, LEAN, etc.).

- Too much focus leads to missed opportunities. The grandiose vision could lead to missed financial targets (Tesla).

- An ideal future unreconciled with the present (Amazon and the toxic work environment).

According to Belgard \& Fisher (1988), good visions have some of the following characteristics:

- Clear, concise and easily understandable

- Memorable

- Exciting and inspiring

- Challenging

- Excellence-centered

The true value of a vision is to guide behavior and help the leadership team to stay true to the organization's focus and intent. There are times when vision statements are not fulfilled and lack authenticity. Wells Fargo's mission statement is to "satisfy their customers' financial needs and help them succeed financially" (Wellsfargo.com, 2019). It has been well documented that Wells Fargo had several ethical challenges in the past few years with illegal behavior by executives and employees. The Justice Department announced they were fining Wells Fargo \$2.09 billion for issuing mortgage loans it knew contained incorrect income information (CNN.com, 2019). Clearly, the leadership team and the employees did not believe in the vision for the organization.

Stian Knutsen, the Norwegian entrepreneur, had a vision to reduce the amount of plastic and corrugated cardboard used in consumer goods packaging through a radical design that no one else had thought of for the past 60 years. He had been reading about the initiative in Europe to reduce the use of plastics and packaging (EU, 2018). Since he did not have a packaging engineering degree, he was not encumbered by previous packaging designs. He dreamt of a new way to reduce the use of plastics and corrugated waste when packaging and shipping consumer goods called Q-Bic, Smart Packaging (Knutsen, 2019). Q-Bic, due to its unique, patented design, reduces the amount of packaging and shipping costs by over $50 \%$. This revolutionary solution helps change the way consumer packaging is used in Europe and the United States and will be seen on retail shelves on both continents in the second half of 2020 . The companies that have signed contracts to commercialize the packaging are Fortune 500 companies in the consumer-packaged goods area in fresh fruit, vegetable and pet products. Mr. Knutsen's vision allowed him to think outside the box and create an innovative packaging design that will help to reduce the global use of plastics, corrugated packaging and the carbon footprint for consumer goods. His perseverance was rewarded with a change the basis of competition, , patentprotected portfolio of products. 


\section{MISSION STATEMENTS}

Mission statements capture the reason of being and the identity for an organization (Wang, 2011). Mission statements are of great relevance to a company and its employees because they facilitate consistency with the implementation of the organization's strategy (Drucker, 1974). Mission statements can also have a significant impact on company performance (Bart, 2001).

A company's mission statement differs from its vision in that it encompasses both the purpose of the company and the basis of competition and competitive advantage (Dess, 2019).

Employees need to internalize the mission statement in order for them to feel the same passion around what the organization is trying to achieve (Campbell, 1992). According to Frederic Marimon, organizations that have people who internalize the mission statement of the company do so under seven dimensions (Marimon, 2015):

- Knowing the content of the mission

- Understanding the importance of the mission

- Visible commitment to the leadership

- Visible commitment of co-workers

- Perceived coherence between mission and practice

- Reflecting on the mission

- Frequently recalling the mission

The dimensions identified by Marimon (2015) go beyond slogans and posters on the wall; they truly help employees internalize the mission of the organization and help bring it to life. Very few mission statements identify profit or any other financial indicator as the sole purpose of the firm (Dess, 2019).

Medtronic has epitomized the importance of an organization that lives its mission statement. John Meslow, a retired Medtronic executive, was one of the original employees and worked with the founder, Earl Bakken. The focus for Medtronic was not on making money and increasing shareholder equity, but helping people live longer and more productive lives. John remembers talking to Bakken about the need for employee non-compete contracts driven by the number of executives leaving Medtronic to start their own medical companies. Bakken's response was, "we do not need non-compete agreements; if they create medical products that help people, then everyone wins" (Meslow, 2019). Bakken believed in the power of doing the right thing and helping the greatest number of people, regardless of whether or not Medtronic received the sale. He was a transformational leader. Meslow (2019) continues his dedication to the community through his Mayo Innovation Scholars Program, which pairs students with Mayo scientists and business managers. The students work with the scientists on projects for future Mayo Clinic businesses - a win-win for everyone.

The entrepreneurs in the nationwide survey were quite clear regarding the need for a mission statement. The majority of the respondents felt a mission statement was critical to the success of the organization. In the authors' work with over 75 entrepreneurs, we have been surprised how many companies did not have a formal business plan or mission statement. The survey results revealed that $46 \%$ of the respondents did not have a written business plan and $41 \%$ of the respondents did not have a mission statement. It's definitely a missed opportunity to help focus and drive the organization toward a common goal.

\section{INNOVATION - IDEATION PROCESS}

"Innovation is having the courage to say no to a thousand things." -- Steve Jobs

Creativity is the seemingly magical capacity to imagine the unseen. Innovation is the act of manifesting the creative into something tangible. Creativity is very simply the action of turning a thought into a thing (Zaboski, Dierberger, \& Douglas, 2016). Innovation involves using new technology to transform organizational processes or create commercially viable products and services (Dess, 2019). There are two different types of innovation: product and 
process. Product innovation centers around creating designs and applications of technologies to create new products or services. Amazon has championed the approach using process innovation. Process innovation is typically associated with improving the efficiency of an organizational process or transforming an industry through a new process. A number of businesses have closed due to changes in consumer behavior and their inability to compete against Amazon and other online retailers.

The research paper focuses on the data collected from the entrepreneur survey, which deals with the front end of the business process and where entrepreneurs receive the inspiration for their business ideas. A critical point of differentiation in new product development and innovation is the need to establish the correct nomenclature and definitions. According to Davila (2013), radical change - a product or service that changes the landscape of business - is rare; according to Davila (2013), only $1 \%$ of the new products introduced into the market fall into the category of radical change (Davila, 2013). In 2007, at Macworld in San Francisco, Steve Jobs introduced the Smart Phone by stating, "We are going to make some history here today." Whether you use an Apple or Android smart phone, we have all benefitted from the introduction of smart phones. The iPhone radically changed the way we communicate and how we conduct business (Gallagher, 2019). In subsequent phone introductions, the changes have become less radical and more incremental. An example would be changing the size of the screen or improving the camera. Davilla (2019) believes incremental change accounts for $95 \%$ of new product introductions with the remaining products falling into the semi-radical and radical change category (Davila, 2013).

New businesses may also spring out of a more personal mission or desire - such as a product that meets a special need for a loved one. For Wendy and Augie Hinnenkamp, their mission was to help their daughter, Chloe, who was born with Eosinophilic Esophagitis (EoE). EoE is a chronic allergic inflammatory disease of the esophagus triggered mainly by food proteins. Eliminating the six foods commonly associated with food allergies (milk, wheat, soy, eggs, nuts and fish) from the diet was an effective treatment for Chloe and the majority of patients with EoE. Her immune system could not tolerate gluten and genetically modified foods. The Hinnenkamp family was in and out of the hospital several times until they could narrow down the reasons for the reactions Chloe was having to certain foods. She was intolerant toward a number of food proteins - for example, anything with peanuts or peanut oil would result in an emergency ambulance trip to the hospital.

The problem they faced was poor labeling by the consumer goods packaging companies and incomplete or inaccurate information. Their food shopping experience was frustrating because of the lack of good tasting packaged foods they could purchase in stores. That frustration led to the creation of Chloe Vegan Foods - delicious plant-based foods for people with EoE, so they're better for animal welfare and better for the future of the planet. Chloe Vegan Foods pizzas and other products help people achieve a heathier diet through vital nutrients, while also offering great taste and fewer calories. The new vegan products use a cauliflower crust and a cheese made from cauliflower and spices. The meatless pepperoni and sausage are made from mushrooms and are exceptional in taste and texture. All Chloe Vegan Foods products are free of soy, dairy, gluten, legumes, eggs and peanuts. The Hinnenkamp family's challenge turned into an opportunity to help their daughter and other children and adults with immune deficiency issues. Chloe turned ten in June 2019 and is doing well. The Hinnenkamp family has made it their life's mission to create awareness for EoE and to help families struggling with how to address the dietary needs of their children. An opportunity, created by a need to provide a better life for their daughter, has turned into a wonderful business designed to help all people with EoE (Gottsacker, 2019).

\section{Vison and Mission Survey Results}

The survey results on the use of vision statements revealed in Table 7 that 42 out of 77 entrepreneurs did not have a formal business plan. However, 44 of the 77 had vision and mission statements. The 77 entrepreneurs started 133 different businesses with $22 \%$ of them starting an average of two enterprises. There is always a myriad of reasons why businesses fail but one common theme was the lack of a formal business plan. The three businesses mentioned in the article all had formal business plans that were adjusted as the market conditions changed. Their ability to pivot and adjust to the market and competitors were critical to their success. Table 7 captures the number of entrepreneurs who answered that portion of the survey. 
Table 7. Survey Results for Vision/Mission Statements

\begin{tabular}{c|c|c|c|c}
\hline Entrepreneurs & $\begin{array}{c}\text { Vision/Mission } \\
\text { statements }\end{array}$ & Businesses started & $\begin{array}{c}\text { Businesses still } \\
\text { existing }\end{array}$ & Businesses failed \\
\hline 77 & $44 / 77$ & 133 & 77 & 56 \\
\hline
\end{tabular}

\section{INSPIRATION FOR THE BUSINESS}

Entrepreneurs see opportunities where other people see problems. Steve Jobs was able connect patterns and dots that led to services like iTunes ${ }^{\circledR}$, a $\$ 10$ billion business that is very profitable for Apple and continues to grow and evolve as streaming becomes the norm (Jarvery, 2018).

Previous research data shows that entrepreneurs receive inspiration for their businesses from their family, friends, business experience and solving an opportunity presented as a problem. Our research shows that the vast majority of respondents received their inspiration from their own ideas, family, friends and business experience. Entrepreneurs have the innate ability to look for problems and turn them into business opportunities. Entrepreneurs like Stian Knutsen and Wendy Hinnenkamp were motivated to create businesses not only to help family and friends but to make a difference in the world for the greatest number of people. Table 8 describes where entrepreneurs received the inspiration for their business ideas. The data shows the vast majority of entrepreneurs received their business ideas from themselves and their business experiences.

Table 8. Survey Results for Business Inspiration

\begin{tabular}{l|c}
\hline \multicolumn{1}{c}{ Inspiration for the idea } & Number of Respondents \\
\hline From a mentor & 6 \\
\hline From a university & 5 \\
\hline From customers & 2 \\
\hline From family & 24 \\
\hline From friends & 20 \\
\hline Business experience & 13 \\
\hline From myself & $\mathbf{2 5 4}$ \\
\hline From the web & 5 \\
\hline Other & 8 \\
\hline
\end{tabular}

One critical point from Table 8 is the data regarding the number of entrepreneurs who generated their own ideas was driven by their past business experiences.

Table 9 breaks down the businesses started by the entrepreneurs by SIC code. The entrepreneurs self-identified restaurants, retail operations and information technology as three of the more significant business opportunities. The authors posit the businesses identified require less capital expenditure and technical expertise and lower barriers to entry. In the "other" category, many of the businesses were in day care and pet services. The entrepreneurs applied what they learned from their past to create new businesses in the same or adjacent spaces. 
Table 9. Survey Results for Business by SIC Code

\begin{tabular}{l|c}
\hline \multicolumn{1}{c}{ Type of Business } & Number of Businesses \\
\hline Agriculture & 5 \\
\hline Automotive & 5 \\
\hline Banking/Finance & 13 \\
\hline Construction & 24 \\
\hline Energy & 9 \\
\hline Healthcare & 29 \\
\hline Information Technology & 46 \\
\hline Manufacturing & 27 \\
\hline Other & 79 (including day care and pet care) \\
\hline Restaurants/Food & 86 \\
\hline Retail & 68 \\
\hline Transportation & 13 \\
\hline
\end{tabular}

Table 9 really drives home the vulnerability of small businesses that are in the restaurant and service industries.

In our research, as indicated in Table 10, approximately half of the entrepreneurs had sales less than $\$ 100,000$ per year and more than half had less than ten employees. However, 65 of the entrepreneurs had sales of over $\$ 1,000,000$ and over 100 employees, which is a strong benchmark for many entrepreneurs. Very few companies ever exceed $\$ 10$ million in sales - less than $1 \%$ cross that threshold according to the Small Business Administration (SBA, 2019).

Table 10. Survey Results for Sales and Number of Employees

\begin{tabular}{|c|c|c|c|}
\hline Sales from last fiscal year & Respondents & Number of employees & Respondents \\
\hline $0-\$ 100,000$ & 170 & Less than 10 & 199 \\
\hline$\$ 100,000-\$ 250,000$ & 41 & $10-50$ & 44 \\
\hline$\$ 250,000-\$ 500,000$ & 37 & $51-100$ & 33 \\
\hline$\$ 500,000-\$ 1,000,000$ & 30 & $101-500$ & 35 \\
\hline$\$ 1,000,000-\$ 2,000,000$ & 22 & & \\
\hline$\$ 2,000,000-\$ 5,000,000$ & 15 & $501-1000$ & 14 \\
\hline$\$ 5,000,000-\$ 10,000,000$ & 15 & $1,000+$ & 14 \\
\hline$\$ 10,000,000$ plus & 13 & & \\
\hline
\end{tabular}

Table 10 demonstrates the difficulty of starting a business, sustaining it and growing the business to a multi-milliondollar entity.

In Table 11, the entrepreneurs were asked what stage of development their business was in at the time of the survey: introduction, development, growth, maturity or decline. Table 11 identifies the lifecycle with approximately half of the businesses were in the introduction and development phases and half were established businesses in the growth, maturity and decline phases. It's a very solid mix of businesses at the different lifecycle phases.

Table 11. Survey Results for Business Stage of Development

\begin{tabular}{l|c}
\hline \multicolumn{1}{c}{ Stages } & Number of respondents \\
\hline Introduction & 56 \\
\hline Development & 110 \\
\hline Growth & 118 \\
\hline Maturity & 43 \\
\hline Decline & 20 \\
\hline
\end{tabular}

Table 12 identifies the amount of time the entrepreneurs have been in business. Over 200 businesses were in the first 12 months of operation. It's often said that more than half of new businesses fail during the first year. According to the Small Business Association (SBA), this isn't necessarily true. The SBA states that only $30 \%$ of new businesses 
fail during the first two years in operation, $50 \%$ during the first five years and $66 \%$ during the first 10 . The SBA goes on to state that only $25 \%$ make it to 15 years or more (SBA, 2019). However, not all of these businesses need to fail. With the right planning, funding and flexibility, businesses have a better chance of succeeding. The authors analyzed the data from the survey and the biggest mistakes that entrepreneurs have made. The failure rate is very high for startups due to lack of cash flow, competition, poor planning, location (retailers), marketing, lack of a business plan, poor internet presence, rigidity in their thinking, and expanding too quickly (SBA, 2019).

Table 12. Survey Results for Business Longevity

\begin{tabular}{l|c}
\hline \multicolumn{1}{c|}{ Amount of Time in Business } & Respondents \\
\hline $0-6$ months & 128 \\
\hline 6 months to 12 months & 94 \\
\hline 12 months to 18 months & 54 \\
\hline 18 months to 36 months & 29 \\
\hline 36 months to 60 months & 22 \\
\hline 60 months or more & 19 \\
\hline
\end{tabular}

The amount of time as a business demonstrates how challenging it is to survive and how Darwinian the business world can be for entrepreneurs.

Table 13 features entrepreneurs' answers to this question: What are two things you did well when starting your business? The respondents listed marketing and advertising as the top reason they were successful, followed by cash flow, finance and having a business plan. One other common factor was hiring the right people. In a small business, one bad employee, who is not working at capacity or is toxic, can sink the organization. John Meslow, a retired Medtronic executive, discussed the importance of having employees who are committed to the vision of the organization and how that passion can help drive the success of the organization (Meslow, 2019). Employees who do not contribute to the growth of the company can sometimes hide in highly matrixed organizations. In small entrepreneurial organizations, a poor performing employee can impact key customers, sales, profits and become a major reason for their company's success or failure. A number of entrepreneur respondents specifically mentioned the employment of better employees as a major reason for their ultimate success.

Entrepreneurs also mentioned the critical importance of in-depth market research regarding competition, price points and market potential before they launched their businesses. The entrepreneur's ability to gauge the interest and desire to purchase the product or service is critical to the success of the organization. 
Table 13. Survey Results for Positive Actions by Entrepeneurs

\begin{tabular}{l|c}
\hline \multicolumn{1}{c}{ What I did right } & Respondents \\
\hline Innovative business idea & 19 \\
\hline Customer service/Hire the right people & 26 \\
\hline Focus & 5 \\
\hline Marketing/Advertising & $\mathbf{3 8}$ \\
\hline Business/Strategic plan & $\mathbf{2 8}$ \\
\hline Finance and cash flow & 1 \\
\hline Promotions & 8 \\
\hline Expert sales & 14 \\
\hline Managing costs & 6 \\
\hline Network & 6 \\
\hline Brand/Great logo & 19 \\
\hline Customers & 14 \\
\hline Mentorship/investors & 20 \\
\hline Market research & 10 \\
\hline Anticipating customer needs & 8 \\
\hline Patience/perseverance & 11 \\
\hline Desire and hard work & 18 \\
\hline Quality of the product & 4 \\
\hline Honesty & 11 \\
\hline Best service & 13 \\
\hline Taking the risk & \\
\hline
\end{tabular}

Table 13 illustrates the importance of having a business plan, managing cash flow and being able to communicate your value proposition to your target customer base through effective, comprehensive marketing programs.

As Bill Gates once said, "it is fine to celebrate success, but it is more important to heed the lessons of failure" (Brandon, 2019). We asked entrepreneurs what they would have done differently in Table 14. The largest category of needs centered around finances and money:

- The majority cited the need for more upfront cash and capital

- The ability to manage cash flow (especially in a seasonal business)

The second largest category talked about the need for sales and marketing:

- Better marketing and promotion

- A better business plan

- More production planning

- The need for branding

- Better networking

A few of the entrepreneurs wished they would have started the businesses earlier and rued the fact they did not hire more qualified people to help grow the business. A few entrepreneurs wished they would have put more time and energy into the business at the beginning. The survey generated a few responses from entrepreneurs who regretted ever starting the business as well as their choice of partners. 
Table 14. Survey Results for Changes by Entrepreneurs

\begin{tabular}{|c|c|}
\hline What I would change? & Number of Respondents \\
\hline More capital upfront & 24 \\
\hline Strategic planning & 9 \\
\hline Slowed spending & 7 \\
\hline Research & 14 \\
\hline Change priorities & 1 \\
\hline Manage cash flow & 21 \\
\hline Had more money & 8 \\
\hline Branding & 2 \\
\hline Hired more people & 15 \\
\hline Mentoring and coaching & 7 \\
\hline Hired better people & 8 \\
\hline Less/more inventory & 4 \\
\hline Understand costs better & 1 \\
\hline Better planning & 12 \\
\hline Better production planning & 6 \\
\hline Networking & 14 \\
\hline Better organized & 6 \\
\hline Sales/More customers & 11 \\
\hline Marketing and promotion & 29 \\
\hline Better website & 9 \\
\hline Anticipate competition & 1 \\
\hline Better execution & 4 \\
\hline Location & 10 \\
\hline Delegate more & 1 \\
\hline Started earlier & 16 \\
\hline Better quality product/service & 12 \\
\hline Have more fun & 6 \\
\hline Dedicate more time & 13 \\
\hline Legal advice & 3 \\
\hline
\end{tabular}

Table 14 demonstrates the importance of effective marketing of your value proposition and managing cash flow. We believe, based on our own personal experiences, that effective cash flow management will help the business persevere and be successful if the value proposition is apparent to the target audience.

In Table 15, entrepreneurs answered the question, what was the main motivation or key driver to start the business? Entrepreneurs start businesses for a variety of reasons, but the top three reasons are income, flexibility and personal growth. Entrepreneurs enjoy running their own businesses and the freedom that comes with it. Some of the primary reasons are the following:

- Income and money

- Flexibility

- Personal growth

- Enjoyment and fun

- Pursue a dream or your passion

- Become independently wealthy

Only a few of the entrepreneurs cited power and recognition as motivating factors. One of the entrepreneurs the authors have worked with is Mary Katherine Menikheim. Ms. Menikheim is a grade schoolteacher in San Francisco who started an essential oils business called Bescentered air fresheners. Her motivation behind the business idea was driven by the needs of her students. She observed that the students after lunch and recess were sluggish and had a difficult time focusing in the classroom. Ms. Menikheim started experimenting with spraying essential oils and scents in the room to help awaken the senses. She realized there was an opportunity for a series of essential oil products that will 
help children focus in the classroom (Menikheim, 2019). Ms. Menikheim, through her desire to help her school children, is now participating in the $\$ 7.7$ billion fragrance market (Byron, 2011).

For Ms. Menikheim, marketing and selling into a large consumer category with a unique value proposition using essential oils is a significant opportunity. Parents heard from their children about the product and they recommended Bescentered for yoga studios, in-home fresheners, gym clubs, and corporations. A product she started making in her garage is now manufactured in an FDA-approved facility and is sold on Amazon, and in a number of regional chain stores. She was motivated to start the business for her students, and now Bescentered has been transformational for her as well, bringing additional income and flexibility to her life. She has grown personally because of the success of the product line.

Table 15. Survey Results for Entrepreneur Motivation

\begin{tabular}{l|c}
\hline \multicolumn{1}{c}{ Motivation to Start the Business } & Respondents \\
\hline Personal growth & $\mathbf{1 2 0}$ \\
\hline Flexibility & $\mathbf{1 5 7}$ \\
\hline Income & $\mathbf{2 4 6}$ \\
\hline More family time & 40 \\
\hline Fulfillment & 29 \\
\hline Product/development & 28 \\
\hline Become independently wealthy & 59 \\
\hline Make a difference & 25 \\
\hline Recognition & 19 \\
\hline Enjoyment/fun & 79 \\
\hline Pursue dream/passion & 66 \\
\hline Helping others & 30 \\
\hline Power & 11 \\
\hline The challenge & 22 \\
\hline Other & 6 \\
\hline
\end{tabular}

\section{SUMMARY}

In the Grimm's Fairy Tale, "The Frog Prince", the moral of the story teaches us that sometimes, what looks like a frog might be a prince in disguise. Entrepreneurs start businesses and some of the businesses are not successful for a variety of reasons; yet they push on. They have to kiss a lot of frogs to find their prince.

The data from the entrepreneurial survey teaches us the motivation that drives entrepreneurs to start businesses, where they get their business ideas from and the importance of business plans.

In summary, entrepreneurs are resilient, motivated by the opportunity to make money, have a strong desire to control their own future, help other people and they want the opportunity to grow as entrepreneurs. They tend to be college educated, have tried multiple businesses, and conceived their idea from their own business challenges, brainstorms and experiences.

The authors are fascinated by the entrepreneurial spirit and the tremendous courage it takes to start and manage your own business. We will continue to explore this topic through a series of additional journal articles in the next few years.

\section{AUTHOR BIOGRAPHIES}

Dr. George Dierberger is an Associate Professor at Augsburg University, Minneapolis, Minnesota. His teaching areas of expertise include innovation and design, leadership, organizational development, change management, international business and strategic management. Research interests primarily focus on the scholarship of entrepreneurship, innovation, and leadership. Dr. Dierberger spent 25 years in a variety of leadership positions at $3 \mathrm{M}$ and continues to consult for entrepreneurial organizations. E-mail: dierberg@augsburg.edu 
Marc Isaacson has been teaching MIS and Statistics at Augsburg University since 2002. Currently he is an Assistant Professor in the Department of Business Administration. His teaching areas of interest include E-Commerce, Project Management and Introductory Statistics. Currently, his research interests include Data Literacy and Business Analytics. Prior to teaching, Marc spent five years in several engineering and management positions in the Hard Disk Drive and Printed Circuit Board industry.

Cory Erickson has been teaching Marketing and Sales Management at Augsburg University since 2016. Currently he is an Assistant Professor in the Department of Business Administration. His teaching areas of interest include Marketing and Sales Management, Managing Innovation and Organizational Behavior. His research interests include Entrepreneurship and Marketing Excellence in Successful Start-Ups. Outside of teaching, Cory has had a successful Marketing and Management career working for Fortune 100 companies all the way to Start-Ups.

Tom Dierberger is a versatile, award-winning communicator with $30+$ years of experience in marketing, branding and promotions. As President of E Street Concept \& Content, he transforms business strategies into creative, compelling messaging that comes to life across a variety of media - from print and digital advertising to websites, videos, email campaigns and social marketing. Recent clients have included Honeywell, Red Wing Shoes, Larson Doors, Spalon Montage and Pearson's Candies. Prior to running his own communications business, Tom held leadership positions at multiple creative agencies in the Twin Cities, as well as within Target and Cargill.

\section{REFERENCES}

Barringer, B., \& Ireland, R. (2019). Entrepreneurship: Successfully Launching New Ventures. New York: Pearson.

Bart, C. K. (2001). Measuring the mission effect in human intellectual capital. Journal of Intellectual Capital, Vol. 2, pp 320330.

Belgard, W., \& Fisher, K.A. (1988). Vision, Opportunity and Tenacity: Three informal processes that influence transformation. San Francisco: Jossey-Bass.

Bosma, N. (2018). Global Entrepreneurship Mnitor. Grafica Andes,: Global Entrepreneurship Research Association.

Brandon, J. (2019, September 11). Inc . Retrieved from www.inc.com: https://www.inc.com/john-brandon/25-of-the-best-billgates-quotes-on-success.html

Byron, E. (2011, March 11). Wall Street Journal. Retrieved from Wall Street Journal : https://www.wsj.com/articles/SB10001424052748704076804576180683371307932

Campbell, A.A. (1992). A Sense of ission: Defining Direction for a Large Organization. Reading: Addison- Wesley.

CNN.com. (2019, January 1). Retrieved from www.CNN.com: https://money.cnn.com/2018/08/01/investing/wells-fargosettlement-mortgage-loans/index.html

Collins, J. (2001). Good to Great. New York: HarperCollins.

Davila. (2013). Innovation. Saddle River: Pearson Education.

Denecke, L. (2019, October 12). Encylopedia Britannica . Retrieved from www.britannica.com: https://www.britannica.com/biography/Brothers-Grimm

Dess, G. G. (2019). Strategic Management. New York: McGraw-Hill.

Drucker, P. (1974). Management: Tasks, Responsibilities. Practices. New York: Harper and Rowe.

Editor. (2018, December 31st). Merrian-webster dictionary. Retrieved from Merriam-webster: https://www.merriamwebster.com/dictionary/entrepreneur

EU. (2018, May 15). EC.Europe environment. Retrieved from EC. Europe: https://ec.europa.eu/environment/waste/plastic waste.htm

Fry, A. (2017, October 23rd). Corporate Scientist. (G. Dierberger, Interviewer)

Gallagher, W. (2019, January 9th). appleinsider.com. Retrieved from Apple Insider: $\mathrm{https}$ //appleinsider.com/articles/19/01/09/when-apple-introduced-the-iphone-on-jan-9-2007-it-was-the-ultimatecomputer-for-the-rest-of-us

GEM. (2019, February 9th). Retrieved from Global Entrepreneurship Monitor: https://www.gemconsortium.org/

Gottsacker, M. (2019, May 2nd ). Chloe Vegan Foods about us. Retrieved from Chloe Vegan Foods: https://chloeveganfoods.com/chloe-difference/

Jarvery, N. (2018, November 1st). Hollywood Reporter. Retrieved from Hollywood Reporter.com: https://www.hollywoodreporter.com/news/apple-hits-10-billion-revenue-services-like-itunes-1157173

Kashyap, R. (2018, August 29th). Doctor. (G. Dierberger, Interviewer)

Kinicki, A. W. (2019). Management: A Practical Application. New York: Mcgraw-Hill.

Knutsen, S. (2019, August 19). CEO. (G. Dierberger, Interviewer)

Marimon, F. M.-M. (2015). Assessing the Internalization of the Mission. Industrial Management and Data Systems, Vol. 116, pp170-187.

Copyright by author(s); $\underline{\text { CC-BY }}$ 
Mayo Clinic. (2019, January 1st). Retrieved from www.mayclinic.com: https://mayoclinichealthsystem.org/locations/eauclaire/about-us/mission-vision-and-value-statements

Menikheim, M. K. (2019, September 30th). Owner. (G. Dierberger, Interviewer)

Meslow, J. (2019, July 18). Retired executive from Medtronic. (D. G. Dierberger, Interviewer)

SBA. (2019, august 19). www.sba.gov. Retrieved from Small Business administration.gov: https://www.sba.gov/business-guide

Wang, Y. (2011). Mission - driven organizations in Japan: managment philosophy and individual outcomes. Journal of Business Ethics, Vol. 101, pp 111-126.

Wellsfargo.com. (2019, January 1). Retrieved from Wells Fargo: https:/www.wellsfargo.com/about/corporate/vision-and-values/ Zaboski, D., Dierberger, G., \& Douglas, R. (2016). The Alchemy of Creativity. American Journal of Management, 66-81. 


\section{NOTES}

